\title{
SISTEM PAKAR DIAGNOSIS PENYAKIT PADA TANAMAN VANILI MENGGUNAKAN METODE DEMPSTER-SHAFER BERBASIS WEB
}

\author{
1 Bambang Hermanto, 2 Albertus Sudirman, 3 Nanda \\ 1,3 Jurusan Ilmu Komputer FMIPA Universitas Lampung \\ 2 Jurusan Budidaya Tanaman Perkebunan Politeknik Negeri Lampung \\ 1 bambang.hermanto@fmipa.unila.ac.id, 22albertus@polinela.ac.id, 3nandammeydhia@gmail.com
}

\begin{abstract}
Vanilla (Vanilla planifolia Andrews) is an industrial plant that has high economic value as a foreign exchange-producing export commodity that is still potential to be developed in Indonesia. Vanilla is widely used in Indonesia as an auxiliary material for the food industry and in fragrance medicine. However, the high demand for vanilla is not balanced with an adequate level of productivity due to several obstacles in the development of vanilla in Indonesia. The main cause of obstacles in vanilla cultivation in Indonesia is the lack of understanding of vanilla farmers regarding diseases that attack vanilla plants. Therefore in this study an expert system was built that could diagnose vanilla plant diseases based on knowledge obtained from the experts directly. Expert system is built based on the web using the PHP programming language and Mysql database. The inference method used is the Dempster-shafer method. In this study consisted of 5 diseases and 16 symptoms data. Test results show that: (1) Expertise testing by comparing the results of expert diagnoses and the system is appropriate and runs very well with a total average accuracy of $99.50 \%$ (2) External testing using a questionnaire involving 20 respondents namely "students of the Plantation Plant Cultivation" show that the system built has an average total percentage value of $82.5 \%$ with the category "Very Good".
\end{abstract}

Keywords: Expert System, Vanilla Plant Disease, Dempster-Shafer

\section{Pendahuluan}

Vanili menjadi modal dasar bagi Indonesia untuk terus memperluas pasaran ekspor, guna meningkatkan penerimaan devisa negara serta meningkatkan pendapatan petani. Peluang pasar komoditas vanili Indonesia masih terbuka luas karena dengan bertambahnya jumlah penduduk dunia, permintaan vanili diperkirakan terus meningkat [1]. Vanili banyak digunakan sebagai bahan pembantu industri makanan dan pewangi obat-obatan (flavour and fragrance ingredients). Industri makanan menggunakan vanili sebagai penyedap atau penambah cita rasa. Industri makanan yang banyak menggunakan vanili sebagai bahan bakunya antara lain industri biskuit, gula-gula, susu, roti, dan es krim. Industri farmasi menggunakannya sebagai pembunuh bakteri dan untuk menutupi bau tidak sedap bahan-bahan lain. Selain itu, aroma vanili yang harum juga bermanfaat sebagai aroma terapi penyegar tubuh dan aphrodistiac [2].

Namun demikian permintaan vanili yang tinggi tersebut tidak diimbangi dengan tingkat produktivitas yang memadai karena adanya beberapa kendala dalam pengembangan vanili di Indonesia. [3] Penyebab utama terjadinya kendala dalam budidaya vanili di Indonesia adalah kurang paham nya petani vanili terhadap penyakit-penyakit yang menyerang tanaman vanili, penyakit-penyakit yang ada menyebabkan kerugian yang sangat besar akibatnya yaitu matinya tanaman vanili (50\%-100\%), memperpendek umur produksi dari 10 kali panen menjadi dua kali, bahkan tidak dapat berproduksi, serta mutu buah sangat rendah. Kalangan petani vanili perlu adanya ahli spesialisasi pertanian terutama ahli tanaman vanili dalam pengambilan keputusan dan kesadaran petani dengan kemajuan teknologi terbaru merupakan hal yang langka, ketersediaan pakar atau ahli manusia yang sangat mahal dan belum tersedia merupakan salah satu kendala lain dalam budidaya vanili di Indonesia. 
[4] Sistem pakar merupakan sistem yang menggunakan pengetahuan manusia ditangkap di komputer untuk memecahkan masalah yang biasanya membutuhkan keahlian manusia. Di bidang pertanian, sistem pakar menyatukan akumulasi keahlian disiplin individu, seperti patologi tanaman, entomologi, hortikultura dan meteorologi pertanian dan Ilmu Hewan.[5] Adanya sistem pakar yang dibuat memungkinkan petani untuk mengambil keputusan yang tepat waktu dengan cara yang efisien, membantu dalam mengurangi biaya dan meningkatkan hasil pertanian. Jadi untuk membantu para petani budidaya vanili dalam mengetahui penyakit-penyakit tanaman vanili dan mengetahui solusi penanganan penyakit vanili dibuat lah sebuah sistem pakar yang dapat mediagnosa penyakit tanaman vanili.

\section{Tinjaun Pustaka}

Vanilimerupakan salah satu tanaman introduksi yang berasal dari Meksiko dan Amerika Tengah. Buahnya banyak digunakan dalam industri makanan, minuman, farmasi, dan kosmetik karena buahnya mengandung vanilli $(\mathrm{C} 8 \mathrm{H} 8 \mathrm{O} 3)$ yang mengeluarkan aroma khas. Batang tanaman vanili termasuk batang monopodial yang berbuku-buku, bentuknya silindris, dan bersifat sukulen. Batangnya berkelok-kelok dan mudah patah, berwarna hijau, dan memiliki stomata sehingga dapat melakukan fotosintesis. Panjang batang bisa bermeter-meter jika dibiarkan tumbuh. Bentuk daun tanaman vanili memenjang sampai lanset. Ujung daun meruncing, sedangkan pangkal daun membulat. Tulang daun bentuknya tidak beraturan dengan jumlah yang banyak. Tangkai daun pendek, tebal, dan beralur menghadap ke atas. Bunga vanili termasuk bunga majemuk tak terbatas yang keluar dari ketiak daun dan jarang bercabang. Mekar bunga dimulai dari pangkal sampai ke ujung, umumnya mekar hanya 1 sampai 3 bunga setiap hari. Warnanya hijau kekuningan dengan diameter $10 \mathrm{~cm}$. Tanaman vanili dapat tumbuh dengan baik pada daerah tropis di antara garis $20^{\circ}$ LU dan $20^{\circ}$ LS pada ketinggian 800 sampai $1.200 \mathrm{~m}$ dpl. Tanaman vanili memiliki 3 jenis, yaitu Vanilla planifolia Andrews, Vanilla tahitensis JW, Moore, dan Vanilla pomopana Schiede[6].

\subsection{Penyakit Tanaman Vanili}

Terdapat beberapa jenis penyakit penting pada tanaman vanili seperti penyakit busuk batang, penyakit antraksona, penyakit bercak coklat pada buah, busuk pangkal batang, dan penyakit karat merah pada tanaman vanili[6].

\subsection{Sistem Pakar}

[7]Sistem pakar adalah suatu sistem informasi yang berusaha mengadopsi pengetahuan dari manusia ke komputer, agar komputer dapat menyelesaikan masalah layaknya seorang pakar. [8] Sistem pakar merupakan cabang dari Artificial Intelligence (AI) yang dikembangkan pada pertengahan tahun 1960. Sistem pakar berasal dari istilah knowledge-based expert system, yaitu sebuah sistem yang menggunakan pengetahuan manusia dimana pengetahuan tersebut dimasukkan kedalam komputer dan kemudian digunakan untuk menyelesaikan masalah-masalah yang biasanya membutuhkan kepakaran atau keahlian manusia.

\subsection{Metode Dempster-Shafer}


Metode Dempster-Shafer adalah suatu penalaran yang digunakan untuk mengatasi ketidakkonsistenan. Ketidakkonsistenan tersebut adalah akibat adanya penambahan fakta baru. Penalaran yang seperti itu disebut dengan penalaran non monotonis. Metode Dempster-Shafer ditulis dalam suatu interval persamaan Belief dan persamaan Plausibility[8].

Persamaan Belief (Bel) adalah ukuran kekuatan evidence dalam mendukung suatu himpunan proposisi. Jika bernilai 0 maka mengindikasikan bahwa tidak ada evidence dan jika bernilai 1 menunjukkan adanya kepastian. Plausibility juga bernilai 0 sampai 1 . Jika yakin akan $\ulcorner$ s, maka dapat dikatakan bahwa $\operatorname{Bel}(\ulcorner\mathrm{s})=1$, dan $\operatorname{PI}(\mathrm{s})=0$. Plausability mengurangi tingkat kepercayaan dari evidence.

[Belief, Plausibility]

$\operatorname{PIs}(\mathrm{X})=1-\operatorname{Bel}(\mathrm{X})=1-\sum_{\mathrm{y} \leq \mathrm{x}} \mathrm{m}(\mathrm{Y})$

Keterangan :

$$
\begin{array}{ll}
\operatorname{Bel}(\mathrm{X}) & =\operatorname{Belief}(\mathrm{X}) \\
\operatorname{Pls}(\mathrm{X}) & =\text { Plausibility }(\mathrm{X}) \\
\mathrm{m}(\mathrm{X}) & =\text { Mass function dari }(\mathrm{X}) \\
\mathrm{m}(\mathrm{Y}) & =\text { Mass function dari }(\mathrm{X}) \\
\mathrm{m} 3(\mathrm{Z}) & =\frac{\sum_{\mathrm{x} \cap \mathrm{y}=\mathrm{z}} \mathrm{m} 1(\mathrm{x}) \cdot \mathrm{m} 2(\mathrm{y})}{1-\sum_{\mathrm{x} \cap \mathrm{y}=\varnothing} \mathrm{m} 1(\mathrm{x}) \cdot \mathrm{m} 2(\mathrm{y})}
\end{array}
$$

Keterangan :

$$
\begin{aligned}
& \mathrm{m} 3(\mathrm{Z}) \quad=\text { Mass function dari evedence }(\mathrm{Z}) \\
& \mathrm{m} 1(\mathrm{x})=\text { Mass function dari evedence }(\mathrm{X}) \text {, yang diperoleh dari nilai keyakinan suatu }
\end{aligned}
$$

\section{Metode Penelitian}

\subsection{Data}

Data yang dibutuhkan pada penelitian ini berupa data penyakit, data gejala, dan nilai kepercayaan serta deskripsi dan penanganannya, data-data tersebut didapatkan dari buku "Budidaya 12 Tanaman Perkebunan Unggulan" [9] dan juga wawancara dengan bapak Ir. Albertus Sudirman ,M.P Dosen Jurusan Budidaya Tanaman Perkebunan Politeknik Negeri Lampung.

\subsection{Metode}

Tahapan penelitian merupakan langkah-langkah yang akan dilakukan selama penelitian berlangsung. Tahapan penelitian dapat dilihat pada Gambar 1. 


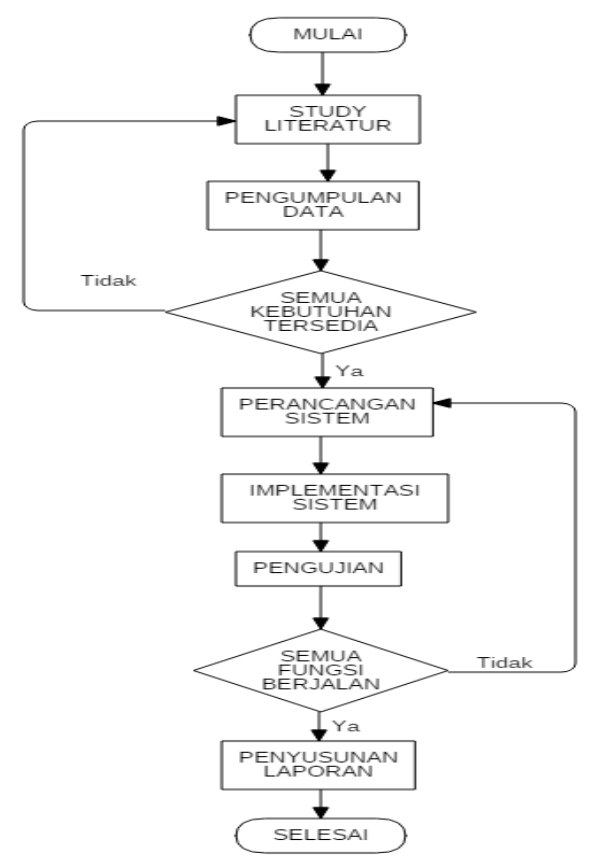

Gambar 1. Diagram alir Tahapan Penelitian

\section{Hasil dan Pembahasan}

Data yang dibutuhkan yaitu 5 jenis penyakit dengan 16 gejala. Untuk data penyakit diberi kode "P001", dan data gejala diberi kode "G001" yang dapat dilihat pada Tabel 1 dan 2.

Tabel 1. Data Penyakit

\begin{tabular}{lll}
\hline Kode & \multicolumn{1}{c}{ Nama Penyakit } & Penyabab \\
\hline P001 & Busuk Batang & Jamur \\
P002 & Antraknosa & Jamur \\
P003 & Bercak Cokelat Pada Buah & Jamur \\
P004 & Busuk Pangkal Batang & Jamur \\
P005 & Karat Merah & Parasit \\
\hline
\end{tabular}

Tabel 2. Data Gejala

\begin{tabular}{ll}
\hline Kode & \multicolumn{1}{c}{ Nama Gejala } \\
\hline G001 & Menyerang tanaman muda vanili usia 3-4 tahun \\
G002 & Batang vanili mengeriput \\
G003 & Warna batang vanili berubah menjadi cokelat
\end{tabular}




\begin{tabular}{|c|c|}
\hline G004 & Sekeliling batang vanili menghitam \\
\hline G005 & $\begin{array}{l}\text { Terdapat bercak cokelat muda kekuningan pada ujung daun } \\
\text { vanili }\end{array}$ \\
\hline G006 & $\begin{array}{l}\text { Terdapat bercak cokelat yang meluas ke semua bagian daun } \\
\text { vanili }\end{array}$ \\
\hline G007 & Daun vanili mengering atau mati \\
\hline G008 & Terdapat bercak cokelat tua pada buah vanili yang membesar \\
\hline G010 & Buah vanili menjadi mengering atau mati \\
\hline G011 & Pangkal batang vanili berair \\
\hline G012 & Pangkal batang vanili berwarna cokelat tua kehitaman \\
\hline G013 & $\begin{array}{l}\text { Terdapat bulu miselium berwarna putih di pangkal batang } \\
\text { vanili }\end{array}$ \\
\hline G014 & Terdapat bercak kecil berbetuk kepingan pada daun vanili \\
\hline G015 & Bagian tengah bercak pada daun mengering atau berlubang \\
\hline G016 & $\begin{array}{l}\text { Bagian pinggir bercak pada daun terus melebar hingga } \\
\text { diameter } 2 \mathrm{~cm}\end{array}$ \\
\hline
\end{tabular}

Untuk mempermudah mengetahui hubungan antara data penyakit dan data gejala maka dibentuk suatu pohon keputusan yang berisi hubungan atau relasi antara data penyakit dan data gejala. Pohon keputusan dapat dillihat pada Gambar 2.

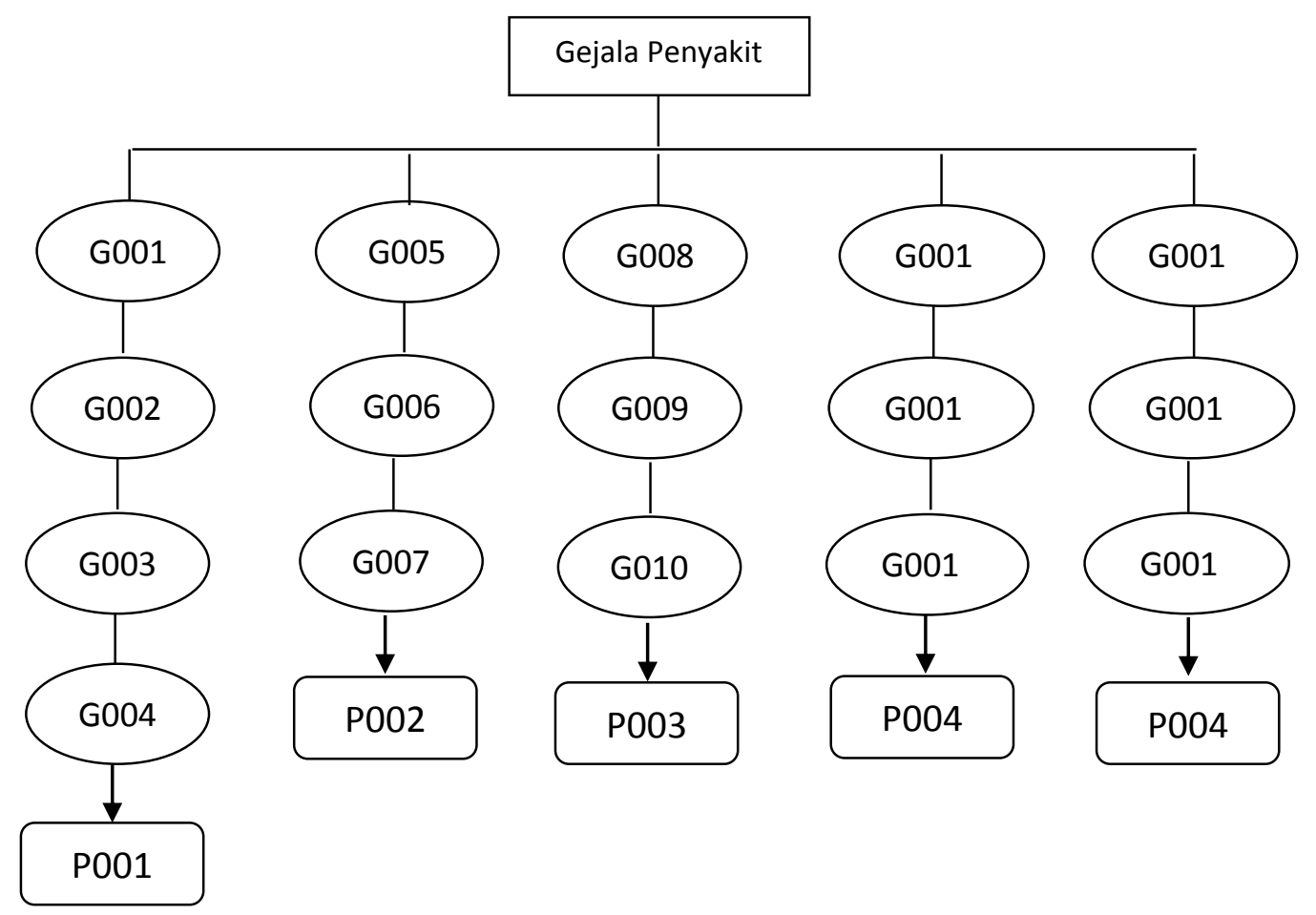




\section{Gambar 2. Pohon Keputusan}

\section{REPRESENTASI PENGETAHUAN}

Representasi pengetahuan yang digunakan yaitu kaidah produksi, yang dituliskan dalam bentuk jika-maka (IF-THEN). Representasi pengetahuan digunakan untuk menentukan proses pencarian dan menentukan kesimpulan. Berdasarkan relasi antara data penyakit vanili dan data gejala tanaman vanili, maka didapatkanlah aturan yang 16 aturan. Nilai kepercayaan merupakan nilai yang digunakan dalam proses diagnosis menggunakan metode Dempster-Shafer. Nilai ini didapatkan melalui konsultasi dengan pakar penyakit tanaman vanili. Aturan-aturan antara data penyaki, data gejala, dan nilai kepercayaan dapat dillihat pada Tabel 3.

Tabel 3. Aturan Hubungan Penyakit dan gejala

\begin{tabular}{|c|c|c|c|}
\hline No & Penyakit & Nama Gejala & $\begin{array}{c}\text { Nilai } \\
\text { Kepercayaan }\end{array}$ \\
\hline \multirow{4}{*}{1} & \multirow{4}{*}{$\begin{array}{l}\text { Busuk } \\
\text { Batang }\end{array}$} & $\begin{array}{l}\text { Menyerang tanaman muda vanili usia 3- } \\
4 \text { tahun }\end{array}$ & 0,7 \\
\hline & & Batang vanili mengeriput & 0,8 \\
\hline & & $\begin{array}{l}\text { Warna batang vanili berubah menjadi } \\
\text { cokelat }\end{array}$ & 0,7 \\
\hline & & Sekeliling batang vanili menghitam & 0,9 \\
\hline \multirow{3}{*}{2} & \multirow{3}{*}{ Antraknosa } & $\begin{array}{l}\text { Terdapat bercak cokelat muda } \\
\text { kekuningan pada ujung daun vanili }\end{array}$ & 0,7 \\
\hline & & $\begin{array}{l}\text { Terdapat bercak cokelat yang meluas ke } \\
\text { semua bagian daun vanili }\end{array}$ & 0,8 \\
\hline & & Daun vanili mengering atau mati & 0,9 \\
\hline \multirow{3}{*}{3} & \multirow{3}{*}{$\begin{array}{l}\text { Bercak } \\
\text { Cokelat } \\
\text { Pada Buah }\end{array}$} & $\begin{array}{l}\text { Terdapat bercak cokelat tua pada buah } \\
\text { vanili yang membesar }\end{array}$ & 0,7 \\
\hline & & $\begin{array}{l}\text { Warna buah vanili berubah menjadi } \\
\text { hitam }\end{array}$ & 0,8 \\
\hline & & $\begin{array}{l}\text { Buah vanili menjadi mengering atau } \\
\text { mati }\end{array}$ & 0,9 \\
\hline \multirow{3}{*}{4} & \multirow{3}{*}{$\begin{array}{l}\text { Busuk } \\
\text { Pangkal } \\
\text { Batang }\end{array}$} & Pangkal batang vanili berair & 0,8 \\
\hline & & $\begin{array}{l}\text { Pangkal batang vanili berwarna cokelat } \\
\text { tua kehitaman }\end{array}$ & 0,9 \\
\hline & & $\begin{array}{l}\text { Terdapat bulu miselium berwarna putih } \\
\text { di pangkal batang vanili }\end{array}$ & 0,9 \\
\hline 5 & $\begin{array}{l}\text { Karat } \\
\text { Merah }\end{array}$ & $\begin{array}{l}\text { Terdapat bercak kecil berbetuk kepingan } \\
\text { pada daun vanili }\end{array}$ & 0,7 \\
\hline
\end{tabular}


Bagian tengah bercak pada daun mengering atau berlubang

Bagian pinggir bercak pada daun terus melebar hingga diameter $2 \mathrm{~cm}$

\section{IMPLEMENTASI SISTEM}

\section{Penerapan Metode Dempster-Shafer}

Perhitungan menggunakan Dempster-Shafer ini digunakan untuk mendapatkan peluang kemungkinan penyakit. Berikut ini merupakan contoh suatu kasus penyakit tanaman vanili:

Tanaman vanili diketahui mengalami gejala sebagai berikut:

- Daun vanili mengering atau mati

- Warna buah berubah menjadi hitam

- Pangkal batang vanili berair

- Pangkal batang vanili berwarna cokelat tua kehitaman

\section{1) Gejala 1}

Daun vanili mengering atau mati adalah gejala dari penyakit Antraknosa (P002) dengan nilai kepercayaan yaitu 0,9 , maka:

$\mathrm{m}_{1}\{\mathrm{P} 002\}=0,9$

$\mathrm{m}_{1}\{\theta\}=1-0,9=0,1$

\section{2) Gejala 2}

Warna buah vanili berubah menjadi hitam adalah gejala dari penyakit Bercak Cokelat Pada Buah (P003) dengan nilai kepercayaan yaitu 0,8 , maka:

$\mathrm{m}_{2}\{\mathrm{P} 003\}=0,8$

$\mathrm{m}_{2}\{\theta\}=1-0,8=0,2$

Dengan gejala baru ini, dihitung nilai densitas $\left(\mathrm{m}_{3}\right)$ untuk kombinasi $\mathrm{m}_{1}$ dan $\mathrm{m}_{2}$. Aturan kombinasi $\mathrm{m}_{3}$ dapat dillihat pada Tabel 4 .

Tabel 4. Aturan kombinasi $\mathrm{m}_{3}$

\begin{tabular}{ccc}
\hline & $\mathrm{m}_{2}\{\mathrm{P} 003\}$ & $\mathrm{m}_{2}\{\theta\}$ \\
& 0,8 & 0,2 \\
\hline $\mathrm{m}_{1}\{\mathrm{P} 002\}$ & $\mathrm{m}_{3}\{\varnothing\}$ & $\mathrm{m}_{3}\{\mathrm{P} 002\}$ \\
0,9 & 0,72 & 0,18 \\
\hline $\mathrm{m}_{1}\{\theta\}$ & $\mathrm{m}_{3}\{\mathrm{P} 003\}$ & $\mathrm{m}_{3}\{\theta\}$ \\
0,1 & 0,08 & 0,02 \\
\hline
\end{tabular}


Lalu dihitung nilai dari densitas $\mathrm{m}_{3}$ sebagai berikut:

$\mathrm{m}_{3}\{\mathrm{P} 002\}=\frac{0,18}{1-0,72}=0,643$

$\mathrm{m}_{3}\{\mathrm{P} 003\}=\frac{0,08}{1-0,72}=0,285$

$\mathrm{m}_{3}\{\theta\}=\frac{0,02}{1-0,72}=0,071$

\section{3) Gejala 3}

Pangkal batang vanili berair merupakan gejala dari penyakit Busuk Pangkal Batang (P004) dengan nilai kepercayan yaitu 0,8 , maka:

$\mathrm{m}_{4}\{\mathrm{P} 004\}=0,8$

$\mathrm{m}_{4}\{\theta\}=1-0,8=0,2$

Dengan gejala baru ini, dihitung nilai densitas baru $\left(\mathrm{m}_{5}\right)$ untuk kombinasi $\mathrm{m}_{3}$ dan $\mathrm{m}_{4}$. Aturan kombinasi $\mathrm{m}_{5}$ dapat dilihat pada Tabel 5.

Tabel 5. Aturan Kombinasi $\mathrm{m}_{5}$

\begin{tabular}{ccc}
\hline & $\mathrm{m}_{4}\{\mathrm{P} 004\}$ & $\mathrm{m}_{4}\{\theta\}$ \\
& 0,8 & 0,2 \\
\hline $\mathrm{m}_{3}\{\mathrm{P} 002\}$ & $\mathrm{m}_{5}\{\varnothing\}$ & $\mathrm{m}_{5}\{\mathrm{P} 002\}$ \\
0.643 & 0,514 & 0,128 \\
\hline $\mathrm{m}_{3}\{\mathrm{P} 003\}$ & $\mathrm{m}_{5}\{\varnothing\}$ & $\mathrm{m}_{5}\{\mathrm{P} 003\}$ \\
0,285 & 0,228 & 0,057 \\
\hline $\mathrm{m}_{3}\{\theta\}$ & $\mathrm{m}_{5}\{\mathrm{P} 004\}$ & $\mathrm{m}_{5}\{\theta\}$ \\
0,071 & 0,057 & 0,014 \\
\hline
\end{tabular}

Lalu dihitung nilai dari densitas $\mathrm{m}_{5}$ sebagai berikut:

$\mathrm{m}_{5}\{\mathrm{P} 002\}=\frac{0,128}{1-(0,514+0,228)}=\frac{0,128}{1-0,743}=0,5$

$\mathrm{m}_{5}\{\mathrm{P} 003\}=\frac{0,057}{1-0,743}=0,22$

$\mathrm{m}_{5}\{\mathrm{P} 004\}=\frac{0,057}{1-0,743}=0,22$

$\mathrm{m}_{5}\{\theta\}=\frac{0,014}{1-0,743}=0,06$

\section{4) Gejala 4}

Pangkal batang vanili berwarna cokelat tua kehitaman merupakan gejala dari penyakit Busuk Pangkal Batang (P004) dengan nilai kepercayan yaitu0,9, maka:

$\mathrm{m}_{6}\{\mathrm{P} 004\}=0,9$

$\mathrm{m}_{6}\{\theta\}=1-0,9=0,1$

Dengan gejala baru ini, dihitung nilai densitas baru $\left(\mathrm{m}_{7}\right)$ untuk kombinasi $\mathrm{m}_{5}$ dan $\mathrm{m}_{6}$. Aturan kombinasi $\mathrm{m}_{7}$ dapat dilihat pada Tabel 6 . 
Tabel 6. Aturan kombinasi $m_{7}$

\begin{tabular}{ccc}
\hline & $\mathrm{m}_{6}\{\mathrm{P} 004\}$ & $\mathrm{m}_{6}\{\theta\}$ \\
& 0,9 & 0,1 \\
\hline $\mathrm{m}_{5}\{\mathrm{P} 002\}$ & $\mathrm{m}_{7}\{\varnothing\}$ & $\mathrm{m}_{7}\{\mathrm{P} 002\}$ \\
0,5 & 0,45 & 0,05 \\
\hline $\mathrm{m}_{5}\{\mathrm{P} 003\}$ & $\mathrm{m}_{7}\{\varnothing\}$ & $\mathrm{m}_{7}\{\mathrm{P} 003\}$ \\
0,22 & 0,2 & 0,022 \\
\hline $\mathrm{m}_{5}\{\mathrm{P} 004\}$ & $\mathrm{m}_{7}\{\mathrm{P} 004\}$ & $\mathrm{m}_{7}\{\mathrm{P} 004\}$ \\
0,22 & 0,2 & 0,022 \\
\hline $\mathrm{m}_{5}\{\theta\}$ & $\mathrm{m}_{7}\{\mathrm{P} 004\}$ & $\mathrm{m}_{7}\{\theta\}$ \\
0,06 & 0,05 & 0,006 \\
\hline
\end{tabular}

Lalu dihitung kombinasi antara $\mathrm{m}_{5}$ dan $\mathrm{m}_{6}$ sebagai berikut:

$\mathrm{m}_{7}\{\mathrm{P} 002\}=\frac{0,05}{1-(0,45+0,2)}=\frac{0,05}{1-0,65}=0,1429$

$\mathrm{m}_{7}\{\mathrm{P} 003\}=\frac{0,022}{1-0,65}=0,0635$

$\mathrm{m}_{7}\{\mathrm{P} 004\}=\frac{(0,2+0,05+0,022)}{1-0,65}=\frac{0,272}{1-0,65}=0,7778$

$\mathrm{m}_{7}\{\theta\}=\frac{0,005}{1-0,65}=0,0587$

Karena tidak ada gejala lagi, maka nilai dari densitas $\mathrm{m}_{7}$ dijadikan sebagai hasil akhir perhitungan. Hasil akhir dapat dilihat pada Tabel 7.

Tabel 7. Hasil akhir

\begin{tabular}{cccc}
\hline No & Penyakit & Nilai Densitas & $\begin{array}{c}\text { Nilai Densitas } \\
\text { (Dalam persen) }\end{array}$ \\
\hline 1. & $\begin{array}{c}\text { Antraknosa } \\
\text { Bercak Cokelat } \\
\text { pada Buah }\end{array}$ & 0,1429 & $14,29 \%$ \\
2. & 0,0635 & $6,35 \%$ \\
3. & $\begin{array}{c}\text { Busuk Pangkal } \\
\text { Batang }\end{array}$ & 0,7778 & $77,78 \%$ \\
\hline
\end{tabular}

Nilai densitas yang tertinggi adalah $\mathrm{m}_{7}\{\mathrm{P} 004\}$ yaitu 0,7778 yang berarti kemungkinan tertinggi untuk penyakit dengan gejala daun vanili mengering atau mati, warna buah vanili berubah menjadi hitam, pangkal batang vanili berair dan pangkal batang vanili berwarna cokelat tua kehitaman adalah Busuk Pangkal Batang.

\section{TAMPILAN HALAMAN PENGGUNA}

Diagnosa merupakan fitur utama yang disajikan dalam sistem pakar ini. Tampilan halaman Diagnosa dapat dilihat pada Gambar 3. 


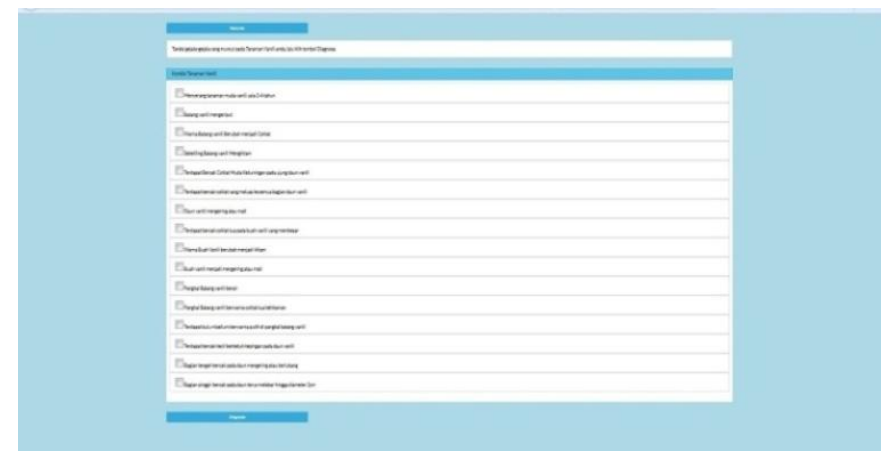

Gambar 3. Tampilan Halaman Diagnosis

Halaman Hasil Diagnosis berisi daftar penyakit hasil diagnosis berdasarkan gejala-gejala yang sudah dipilih. Daftar penyakit ini diurutkan berdasarkan penyakit dengan kemungkinan paling besar ke paling kecil. Pengguna dapat mengklik nama penyakit untuk beralih ke Halaman Detail penyakit. Halaman Hasil Diagnosis di tunjukkan pada Gambar 4.

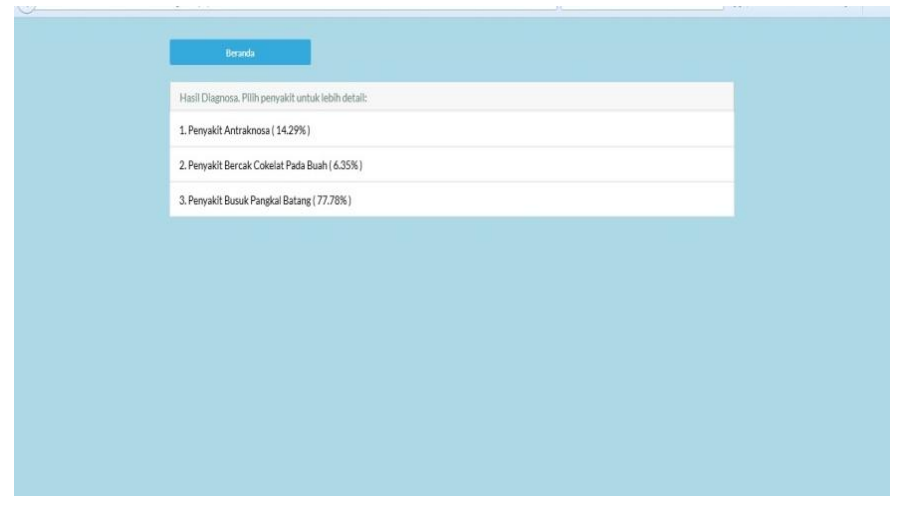

Gambar 4. Tampilan Halaman Hasil Diagnosis

Pengguna dapat melihat informasi mengenai penyakit tanaman vanili yang dipilih melalui halaman detail penyakit, informasi tersebut berupa nama penyakit, penyebab penyakit, deskripsi penyakit, gejela-gejala penyakit, penanganan penyakit, dan gambar penyakit. Halaman Detail Penyakit ditunjukkan pada Gambar 5.

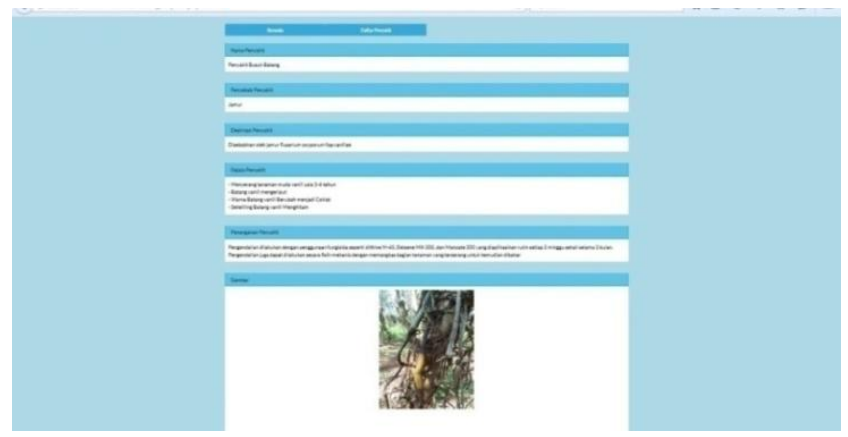

Gambar 5. Tampilan Halaman Detail Penyakit 


\section{Pengujian}

\section{1) Pengujian Kepakaran}

Pengujian kepakaran bertujuan untuk menguji kemampuan sistem pakar dalam melakukan diagnosa penyakit berdasarkan fakta-fakta yang diberikan.Berdasarkan hasil pengujian kepakaran yang telah dilakukan dapat dikatakan bahwa sistem dapat mendiagnosis penyakit dengan sangat baik sesuai dengan hasil diagnosis yang dilakukan oleh pakar dengan total rata-rata keakurasian sebesar $99,50 \%$.

\section{2) Pengujian Kepuasan Pengguna}

Berdasarkan kuesioner yang melibatkan 3 responden I yaitu "Pakar" menunjukan bahwa sistem yang dibangun memiliki nilai presentase total rata-rata $85 \%$ dengan kategori "Sangat baik", dan 20 responden II yaitu mahasiswa Jurusan Budidaya Tanaman Perkebunan menunjukkan bahwa sistem yang dibangun memiliki nilai persentase total rata-rata $82,5 \%$ dengan kategori "Sangat Baik".

\section{Kesimpulan}

Berdasarkan penelitian yang telah dilakukan, diperoleh beberapa kesimpulan sebagai berikut:

1. Telah berhasil dibangun aplikasi sistem pakar untuk mendiagnosa penyakit tanaman vanili menggunakan metode Dempster-Shafer berbasis web guna membantu pengguna diantaranya petani vanili untuk mendiagnosa penyakit pada tanaman vanli berdasarkan gejala-gejala yang muncul.

2. Hasil pengujian kepakaran yang telah dilakukan dapat dikatakan bahwa sistem dapat mendiagnosis penyakit dengan sangat baik sesuai dengan hasil diagnosis yang dilakukan oleh pakar dengan total rata-rata keakurasian sebesar 99,50\% .

\section{Daftar Pustaka}

[1] Pusat Data dan Informasi Pertanian. 2009."Outlook Komoditas Perkebunan”. Jakarta.

[2] Ali Mustofa Nuzula. 2013. "Permintaan Ekspor Vanili Indonesia ke Amerika Serikat dengan Pendekatan Error Correction Model”. Semarang.

[3] Endang Nurchyani, dkk. 2012. "Penekanan Perkembangan Penyakit Busuk Batang Vanili Melalui Seleksi Asam Furusat Secara In Vitro”. J. HPT Tropika. ISSN 1411-7525. Vol. 12, No. 1: $12-22$.

[4] Malik, Meenakshi,dkk.2018." Review Paper On Decision Support System/Expert System Developed On Mango". International Journal Of Plant Protection Volume 11 Issue 1, Hal. 119-123. Issn-0976-6855. 
[5] Gandhi,N,dkk.2014." Application Of Expert Systems In Agriculture”.International Journal Of Pure And Applied Research In Engineering And Technology. Volume 3 (1): 86-94. ISSN: 2319-507X.

[6] Suwarto, Yuke Octavianty, dan Silvi Hermawati. 2014. "TOP 5 Tanaman Perkebunan”. Jakarta: Dok. Penebar Swadaya.

[7] Sri Kusumadewi.2003. "Artificial Intelligence (Teknik dan Aplikasinya)". Yogyakarta: Graha Ilmu.

[8] Sutojo, T., Edy M., dan Vincent S. 2011. “Kecerdasan Buatan”. Yogyakarta : Andi.

[9] Suwarto.2010. “ Budidaya 12 Tanaman Perkebunan Unggulan ”. Jakarta: Penebar Swadaya. 